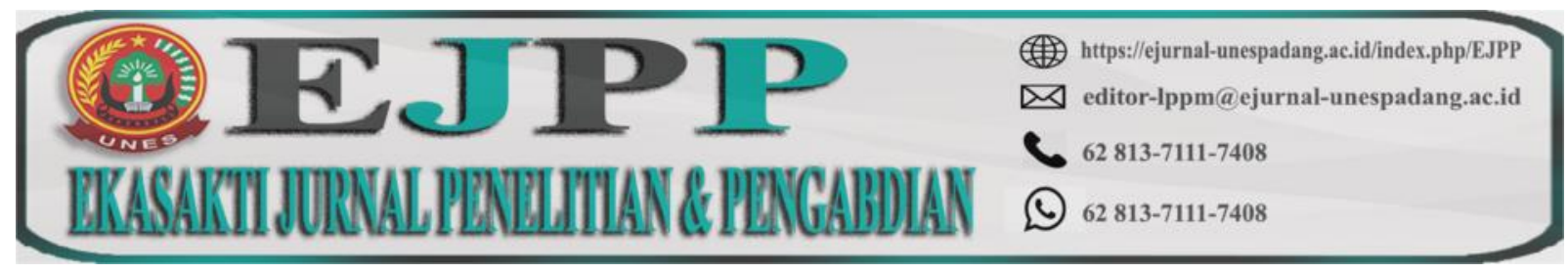

DOI: https://doi.org/10.31933/ejpp.v1i1

Received: 26/09/2020, Revised: 31/10/2020, Publish: 22/11/2020

\title{
VALIDITAS ANGKET FAKTOR-FAKTOR YANG MEMPENGARUHI KECANDUAN GAME ONLINE PADA SISWA SMA SWASTA SE- KOTA PADANG
}

\author{
Nela Sari Yolanda ${ }^{1}$, dan Yessy Marzona ${ }^{2}$ \\ 1) Program studi Pendidikan Matematika, FKIP Universitas Ekasakti Padang. \\ Email: nelasari_yolanda@yahoo.co.id \\ 2) Program studi Pendidikan Bahasa Inggris, FKIP Universitas Ekasakti Padang. \\ Email: yessy.marzona@gmail.com
}

\begin{abstract}
ABSTRAK
Penelitian ini memiliki tujuan untuk melihat faktor-faktor yang mempengaruhi kecanduan bermain game online. Melihat perkembangan game online saat ini, dampak negatifnya yaitu kecanduan. Oleh karena itu dibuatlah angket untuk melihat tingkat kecanduan siswa SMA swasta se-kota Padang. Sebelum angket disebarkan maka perlu diperlukan validasi terhadap angket. Angket di validasi oleh 3 validator yaitu 2 ahli matematika dan 1 ahli Bahasa. Aspekaspek yang dinilai oleh validator adalah aspek Bahasa, aspek permasalahan dan aspek tujuan. Hasil validasi menunjukkan bahwa angket sudah valid dari setiap aspek yang dinilai.
\end{abstract}

Kata Kunci: Kecanduan, Game Online, Angket, Aspek, Validitas

\begin{abstract}
This study aims to find out the factors that influence addiction to playing online games. Realizing the development of online games which has a results as an addiction. Therefore a questionnaire was constructed to see the addiction level of private high school students in the city of Padang. Before the questionnaire is distributed it is necessary to validate the questionnaire. The questionnaire was validated by 3 validators, 2 mathematicians and 1 linguist. The aspects assessed by the validator are aspects of language, aspects of problems and aspects of objectives. The results of the validation has shown that the questionnaire was valid for every aspect assessed.
\end{abstract}

Keywords: Addiction, Online Game, Questionnaire, Aspects, Validit 


\section{PENDAHULUAN}

Salah satu kemajuan dari teknologi di era globalisasi ini yaitu internet. Pengguna internet mayoritas merupakan penduduk berusia muda dan produktif. Horrigan (2002) mengklasifikasikan aktivitas-aktivitas yang dilakukan pengguna internet salah satunya adalah aktivitas kesenangan dan hiburan. Game online sebagai salah satu aktivitas kesenangan dimainkan dengan menggunakan jaringan internet. Salah satu pengguna yang muda dan produktif adalah siswa. Siswa pada penelitian ini adalah siswa Sekolah Menengah Atas. Dampak negatif dari game online bagi siswa adalah siswa akan malas belajar dan sering menggunakan waktu luang mereka untuk bermain game online, siswa akan mencuri curi waktu dan jadwal belajar mereka untuk bermain game online, waktu untuk belajar dan membantu orang tua sehabis jam sekolah akan hilang karena main game (Masya dan Candra, 2016). Game online merupakan bagian dari internet yang sering dikunjungi dan sangat digemari dan bisa menyebabkan kecanduan yang memiliki intensitas yang sangat tinggi. Sedangkan kecanduan merupakan perasaan yang sangat kuat terhadap sesuatu yang diinginkan. Dari uraian di atas dapat disimpulkan pengertian kecanduan game online adalah suatu keadaan seseorang terikat pada kebiasaan yang sangat kuat dan tidak bisa lepas untuk bermain game online.

Menurut Saputra (2016), faktor yang mempengaruhi remaja kecanduan game online yaitu gender, kondisi psikologis, dan jenis game. Smart (Kusumawati, 2017), menyatakan bahwa salah satu faktor yang dapat menyebabkan anak mengalami kecanduan game online karena merasa kurang perhatian dari orang-orang terdekat termasuk orang tua. Sedangkan menurut Yuniar (2008), faktor-faktor yang mempengaruhi kecanduan game online yaitu penyediaan sarana internet, faktor individu, kelompok usia, dan alasan bermain. Berdasarkan pendapat di atas maka dapat disimpulkan bahwa aspek-aspek kecanduan game online yaitu: waktu, aspek kurangnya kontrol, aspek biaya, aspek pertahanan, dan aspek perasaan.

\section{METODE PENELITIAN}

Jenis penelitian ini adalah penelitian terapan yaitu menerapkan suatu permasalahan ke dalam kehidupan sehari-hari yang diawali dengan analisis teori dan diikuti dengan pengambilan data. Pada penelitian ini, data yang diperoleh dideskripsikan setelah dilakukan penerapan dari analisis regresi logistik terhadap data tersebut. Jenis data yang digunakan dalam penelitian ini adalah data primer. Responden dalam penelitian ini adalah siswa SMA swasta se-Kota Padang yang sedang bermain game online di smartphone mereka.

Populasi pada penelitian ini adalah seluruh siswa SMA swasta se-Kota Padang yang sedang bermain game online di smarphone. Teknik pengambilan sampel dalam penelitian ini menggunakan teknik non probability sampling dengan metode accidental sampling. Teknik non probability sampling adalah metode pengambilan sampel yang memberi peluang tidak sama bagi setiap anggota populasi untuk dipilih menjadi sampel karena pertimbangan tertentu (Sugiyono, 2011). Alat pengumpul data dalam penelitian ini adalah angket yang disusun dengan menggunakan skala Likert. Menurut Arikunto (2010), kuesioner adalah sejumlah pernyataan 
tertulis yang digunakan untuk memperoleh informasi dari responden dalam arti laporan tentang pribadinya, atau hal-hal yang ia ketahui.

Angket yang telah disusun kemudian dilakukan dahulu validasi angket. Validasi angket adalah prosedur untuk memastikan apakah angket yang akan dipakai untuk mengukur variabel penelitian valid atau tidak. Valid berarti kuesioner tersebut dapat digunakan untuk mengukur apa yang hendak diukur. Angket ada yang sudah baku, karena telah teruji validitas dan reliabilitasnya, tetapi banyak juga yang belum baku. Jika kita menggunakan angketyang sudah baku, tidak perlu dilakukan uji validitas lagi, sedangkan kuesioner yang belum baku perlu dilakukan validasi.

Angket di validasi oleh 3 validator yaitu 2 ahli matematika dan 1 ahli Bahasa. Aspekaspek yang dinilai oleh validator adalah aspek Bahasa, aspek permasalahan dan aspek tujuan. Data yang dihasilkan tersebut dianalisis secara deskriptif. Data yang ada dihitung menggunakan rumus yang ada di dalam Muliyardi (2006) yaitu:

$$
R=\frac{\sum V}{N}
$$

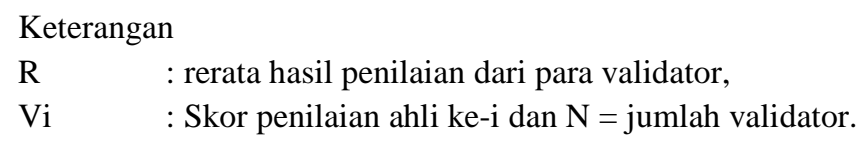

Kemudian rerata yang didapatkan dikonfirmasikan dengan kriteria yang ditetapkan. Cara mendapatkan kriteria tersebut adalah sebagai berikut:

1. Rentangan skor mulai dari $0-4$

2. Kriteria dibagi atas lima tingkatan. Istilah yang digunakan disesuaikan dengan karakteristik aspek-aspek yang dinilai.

3. Rentangan rerata dibagi menjadi lima kelas interval.

Misalnya, untuk aspek rumusan kompetensi digunakan kriteria dengan istilah sebagai berikut: 1). Jika rerata > 3,20 maka aspek yang dinilai dikategorikan sangat valid; 2). 2,40 < rerata $\leq 3,20$ valid; 3 ). 1,60 < rerata $\leq 2,40$ cukup valid; 4 ). $0,80<$ rerata $\leq 1,60$ kurang valid; dan 5). Jika rerata $\leq 0,80$ maka aspek yang dinilai dikategorikan tidak valid.

\section{HASIL DAN PEMBAHASAN}

Angket yang telah dirancang dan didiskusikan dengan anggota penelitian, selanjutnya divalidasi oleh pakar matematika yang terdiri dari 2 orang dosen pendidikan matematika FKIP Universitas Ekasakti (UNES) yaitu Khurnia Budi Utami, S.Pd., M.Pd, Yuliani Fitri, S.Pd.I., M.Pd, dan 1 orang dosen pendidikan bahasa FKIP Universitas Ekasakti yaitu Eva Fitrianti, S.S., M.Pd selama dua minggu. Berdasarkan saran-saran dari validator dilakukan revisi tehadap angket dan kembali didiskusikan dengan validator. Dari hasil diskusi, validator menyetujui bahwa angket tersebut telah dapat di ujicobakan. Secara garis besar hasil validasi angket aspek Bahasa dapat dilihat pada Tabel 1 berikut. 
Tabel 1. Hasil Validasi Angket dari Aspek Bahasa

\begin{tabular}{|c|c|c|c|c|c|c|c|}
\hline \multirow[b]{2}{*}{ No. } & \multirow[b]{2}{*}{ Indikator } & \multicolumn{5}{|c|}{ Penilaian Validator } & \multirow[b]{2}{*}{ Kesimpulan } \\
\hline & & 1 & 2 & 3 & Jumlah & $\begin{array}{c}\text { Rata- } \\
\text { rata }\end{array}$ & \\
\hline 1. & $\begin{array}{l}\text { Menggunakan kaidah bahasa yang baik dan } \\
\text { benar }\end{array}$ & 3 & 3 & 4 & 10 & 3,3 & Sangat valid \\
\hline 2. & $\begin{array}{l}\text { Kalimat disusun dengan jelas, sederhana, dan } \\
\text { tidak menimbulkan penafsiran ganda }\end{array}$ & 3 & 3 & 3 & 9 & 3 & valid \\
\hline 3. & Penggunaan bahasa yang mudah dipahami & 4 & 3 & 3 & 10 & 3,3 & Sangat valid \\
\hline 4. & $\begin{array}{l}\text { Kalimat yang digunakan mewakili } \\
\text { permasalahan }\end{array}$ & 4 & 3 & 4 & 11 & 3,67 & Sangat valid \\
\hline 5. & $\begin{array}{l}\text { Menggunakan peristilahan yang sesuai } \\
\text { dengan konsep pada pokok permasalahan }\end{array}$ & 3 & 3 & 3 & 9 & 3 & valid \\
\hline \multirow[t]{3}{*}{6.} & Kalimat yang digunakan tepat sasaran & 4 & 3 & 3 & 10 & 3,3 & Sangat valid \\
\hline & Jumlah & 21 & 18 & 20 & 59 & 19,67 & \\
\hline & Rata-rata & & & & & 3,3 & Sangat valid \\
\hline
\end{tabular}

Hasil yang disajikan dalam Tabel 1 menggambarkan bahwa hasil validasi angket untuk aspek bahasa yang dirumuskan tergolong sangat valid dengan rata-rata 3,3. Dapat disimpulkan bahwa tuntunan yang terkandung didalamnya jelas sekali. Dapat disimpulkan bahwa kalimat yang digunakan sesuai dengan kaidah Bahasa Indonesia, melibatkan kemampuan berpikir logis, struktur kalimat sesuai dengan intelektual siswa, kalimat digunakan dengan menggunakan ejaan yang baku, komunikatif. Rekapitulasi hasil validasi angket untuk aspek permasalahan dapat dilihat pada Tabel 2 berikut.

Tabel 2. Aspek Permasalahan

\begin{tabular}{|c|c|c|c|c|c|c|c|}
\hline \multirow[b]{2}{*}{ No. } & \multirow[b]{2}{*}{ Indikator } & \multicolumn{5}{|c|}{ Penilaian Validator } & \multirow[b]{2}{*}{ Kesimpulan } \\
\hline & & 1 & 2 & 3 & Jumlah & $\begin{array}{c}\text { Rata- } \\
\text { rata }\end{array}$ & \\
\hline & $\begin{array}{l}\text { Permasalahan yang digunakan cukup jelas } \\
\text { dan spesifik }\end{array}$ & 3 & 4 & 3 & 10 & 3,33 & Sangat valid \\
\hline 2. & $\begin{array}{l}\text { Permasalahan yang digunakan } \\
\text { berkaitan dengan bidang peneliti }\end{array}$ & 4 & 4 & 3 & 11 & 3,67 & Sangat valid \\
\hline 3. & $\begin{array}{l}\text { Permasalahan kecanduan media sosial } \\
\text { cocok dianalisis menggunakan analisis } \\
\text { regresi logistik ordinal }\end{array}$ & 3 & 4 & 4 & 11 & 3,67 & Sangat valid \\
\hline 4. & $\begin{array}{l}\text { Instrumen yang digunakan sudah dapat } \\
\text { menjelaskan permasalahan secara rinci }\end{array}$ & 4 & 3 & 4 & 11 & 3,67 & Sangat valid \\
\hline 5. & $\begin{array}{l}\text { Lokasi dan objek penelitian sesuai dengan } \\
\text { permasalahan yang digunakan }\end{array}$ & 4 & 3 & 4 & 11 & 3,67 & Sangat valid \\
\hline & Jumlah & 18 & 18 & 18 & 54 & 18 & \\
\hline & Rata-rata & & & & & 3,6 & Sangat valid \\
\hline
\end{tabular}

Hasil yang disajikan dalam Tabel 2 menggambarkan bahwa hasil validasi angket untuk aspek permasalahan yang dirumuskan tergolong sangat valid dengan rata-rata 3,6. Dapat disimpulkan bahwa permasalahan-permasalahan yang disajikan dalam angket sesuai dengan 
tujuan penelitian. Rekapitulasi hasil validasi angket untuk aspek tujuan dapat dilihat pada Tabel 3 berikut.

Tabel 3. Validasi angket Aspek Tujuan

\begin{tabular}{|c|c|c|c|c|c|c|c|}
\hline \multirow[b]{2}{*}{ No. } & \multirow[b]{2}{*}{ Indikator } & \multicolumn{5}{|c|}{ Penilaian Validator } & \multirow[b]{2}{*}{ Kesimpulan } \\
\hline & & 1 & 2 & 3 & Jumlah & $\begin{array}{c}\text { Rata- } \\
\text { rata }\end{array}$ & \\
\hline 1. & $\begin{array}{l}\text { Analisis yang digunakan dapat menjelaskan } \\
\text { permasalahan secara jelas dan rinci }\end{array}$ & 3 & 3 & 3 & 9 & 3 & Valid \\
\hline 2. & $\begin{array}{l}\text { Penelitian yang dilakukan dapat mengatasi } \\
\text { permasalahan yang terjadi }\end{array}$ & 2 & 3 & 3 & 8 & 2,67 & Valid \\
\hline 3. & $\begin{array}{l}\text { Penelitian yang dilakukan dapat digunakan } \\
\text { sebagai contoh pembelajaran dari analisis } \\
\text { Regresi Logistik }\end{array}$ & 4 & 4 & 3 & 11 & 3,67 & Sangat Valid \\
\hline \multirow[t]{3}{*}{4.} & $\begin{array}{l}\text { Penelitian yang digunakan dapat menjadi } \\
\text { pedoman atau panduan bagi orang lain untuk } \\
\text { mengatasi permasalahan kecanduan game } \\
\text { online }\end{array}$ & 3 & 3 & 3 & 9 & 3 & Valid \\
\hline & Jumlah & 12 & 13 & 12 & 37 & 12,33 & \\
\hline & Rata-rata & & & & & 3,08 & Valid \\
\hline
\end{tabular}

Pada Tabel 3 dilihat bahwa hasil validasi angket untuk aspek tujuan yang dirumuskan tergolong valid dengan rata-rata 3,08. Dapat disimpulkan bahwa tujuan penelitian ini tergambar dalam angket yang telah disusun.

Untuk itu perlu perbaikan pada angket yang telah dirancang dengan menyesuaikan saransaran dari validator. Saran-saran yang diberikan didiskusikan terlebih dahulu bersama validator. Menurut Trianto (2010:255), valid berarti bahwa penilaian sudah memberikan informasi yang akurat tentang media yang dikembangkan. Dari hasil penilaian angket oleh validator, telah memberikan informasi-informasi yang dibutuhkan oleh siswa untuk materi bangun datar.

\section{KESIMPULAN}

Penelitian ini bertujuan untuk melihat faktor-faktor yang mempengaruhi kecanduan bermain game online pada siswa SMA se-Kota Padang. Dari pembahasan hasil penelitian dapat disimpulkan hal-hal sebagai berikut: Validitas angket telah dinilai oleh para validator dari berbagai bidang kajiannya, yaitu dari aspek bahasa sebesar 3,3 dengan nilai sangat valid, aspek permasalahan sebesar 3,6 dengan nilai sangat valid, dan aspek tujuan sebesar 3,08 dengan nilai valid. Dapat disimpulkan angket dapat digunakan untuk mengukur semua nilai yang diinginkan dalam penelitian ini.

\section{UCAPAN TERIMA KASIH}

Tim Peneliti berterimakasih kepada Direktorat Riset dan Pengabdian Masyarakat Diputi Bidang Penguatan Riset dan Pengembangan Kementerian Riset dan Teknologi/Badan Riset dan 
Inovasi Nasional yang telah membantu mendanai pelaksanaan penelitian ini sesuai dengan

Kontrak Pelaksanaan Penelitian dengan LLDIKTI Wilayah X Nomor : 077/LL10/PG/2020.

\section{REFERENSI}

Agresti, Allan. 2002. Categorical Data Analysis. New York: John Wiley and Sons.

Aji, Candra Zebeh. 2012. Berburu Rupiah Lewat Game Online. Yogyakarta: Bounabooks.

Arikunto, Suharsimi. 2010. Prosedur Penelitian Suatu Pendekatan Praktik. Jakarta: PT Rineka Cipta.

Arikunto, Suharsimi. 2003. Dasar-dasar Penelitian Suatu Pendekatan Praktek. Jakarta: PT Bumi Aksara.

Badudu dan Zain. 2005. Pengertian Pengaruh Kecanduan Game Online pada Remaja. htpp://dspace. widyatama.ac.id/bitstream/handle/10364/1037/bab2.apdf?sequence=4. $\quad[14$ Agistus 2020].

Beranuy, M., Carbonell, X., \& Griffiths, M. D. 2013. A Qualitative Analysis Of Online Gaming. International Journal of Mental, 11, 149-161.

Brian, D., \& Wiemer-Hastings, J. (2005). Addiction To The Internet And Online Gaming. Journal cyberpsychology and behavior, 8, 2.

Budiman, H. P. 2009. Dunia Mewaspadai Game Online, Indonesia Kapan?. Psikologi Plus (Majalah). Vol I Edisi Maret. 39-43.

Gunarsa, S.D., dan Gunarsa, Y.S.D. 1998. Psikologi Perkembangan Anak dan Remaja. Jakarta: BPK Gunung Mulia.

Hurlock, Elizabeth B. 1980. Psikologi Perkembangan. Erlangga : Gelora Aksara Pratama.

Hosmer and Lemeshow, W. 1989. Applied Logistic Regression. Canada: A Wiley Interscience Publication.

Kartasasmita, Sandi dan Nirmala, Carana. 2012. Gambaran Mindfulness pada Remaja yang Kecanduan Bermain Game Online. https://www.researchgate.net/publication/264550255. [14 Agistus 2020].

Kusumawati, Rosi., Irna Aviani, Yolivia., \& Molina, Yosi. 2017. Perbedaan Tingkat Kecanduan (Adiksi) Games Online Pada Remaja Ditinjau Dari Gaya Pengasuhan. Journal psikologi, 89.

Makridarkis, Spyros. 1999. Metode dan Aplikasi Peramalan. Jakarta : Binarupa Aksara.

Masya, Hardiyansyah., \& Candra, Adi Dian. 2016. Faktor-faktor yang Mempengaruhi Perilaku Gangguan Kecanduan Game Online Pada Remaja Peserta Didik Kelas X di Madrasah 
Aliyah Al Furqoon Prabumuluh Tahun Pelajaran 2015/2016. Journal Bimbingan dan Konseling, 03, 153-159.

Montgomery, Douglas, Peck, Elizabeth, dan Vining, Geoffrey. 2006. Introduction to Linear Regression Analysis, Fourth Edition, USA: Wiley-Intersicience Publication.

Monks, F. J, Knoers, A.M.P, \& Haditono, S.R. 1982. Psikologi Perkembangan : Pengantar Dalam Berbegai Bagiannya. Yogyakarta : Gadjah Mada University Press.

Muhidin, Sambas Ali, dkk. 2007. Analisis korelasi, Regresi dan Jalur dalam Penelitian. Bandung: Pustaka Setia.

Rini, A. 2011. Menanggulangi Kecanduan Game Online Pada Anak. Jakarta. Pustaka Mina.

Saputra, Rahmadi. 2016. Hubungan Kecanduan Game Online Clash of Clans Terhadap Prestasi Akademik Mahasiswa Ilmu Komunikasi Fakultas Ilmu Sosial dan Politik Univesitas Riau. JOM FISIP Vol. 3 No. ,. 5-6

Singarimbuan, Masri dan Effendi, Sofian. 2011. Metode Penelitian Survai. Jakarta: PT Pustaka LP3ES Indonesia.

Sugiyono. 2012. Memahami Penelitian Kualitatif. Penerbit CV. Alfabeta. Bandung.

Surya, Yuyun W.I, 2002, Pola Konsumsi dan Pengaruh Internet sebagai Media Komunikasi Interaktif pada Remaja (Studi Analisis Persepsi pada Remaja di Kotamadya Surabaya), Lembaga Penelitian Universitas Airlangga, Surabaya.

Suryabrata, Sumadi. 2012. Metodologi Penelitian. Jakarta: PT Raja Grafindo Persada.

Susanti, Y. 2008. Ketergantungan pada internet: game online, Video games dan sejenisnya. Anima: Indonesian psychological journal, 23, 180-183.

Umar, Husein. 2005. Metode Penelitian Untuk Skripsi dan Tesis Bisnis. Jakarta: PT Raja Grafindo Persada.

Yanto, Riki, 2001. Pengaruh Game Online Terhadap Perilaku Remaja. Skripsi. Padang: Fakultas Ilmu Sosial dan Ilmu Politik Universitas Andalas.

Yuniar, S. 2008: Ketergantungan Pada Internet : Game Online, Video Game, dan sejenisnya. Anima : Indonesia Psychological Journal. Vol. 23, No.2 (180-183).

Ziqri, Aulia. 2010: Faktor-faktor yang Mempengaruhi Partisipasi Politik Masyarakat Kecamatan Koto Tangah dalam Pelaksanaan Pemilihan Walikota dan Wakil Walikota Padang Tahun 2013 Menggunakan Analisis Regresi Logistik. Tugas Akhir. Program Studi Statistika Jurusan Matematika FMIPA UNP. 